\title{
Which Pathways Should Indonesia Follow to Achieve Its Energy Development Goals into the Future?
}

\author{
Hanan Nugroho \\ Ministry of National Development Planning/Bappenas \\ nugrohohn@bappenas.go.id
}

\section{Introduction}

Indonesia already has a plan for its energy sector development far into the future. Based on the forecast of the future energy demand (2025 and 2050), the plan offers scenarios of meeting those energy needs with certain types of energy and their targeted shares. The types of energy used to meet the increasing demand are grouped into four clusters: coal, oil, natural gas, and renewable energy. The supply scenario takes into account the wealth of Indonesia's energy resources and orders that the share of renewable energy will increase and become the largest by 2050.

The plan is stipulated in the Regulation of Government No. 79 of 2014 concerning National Energy Policy. It has been explicated into Presidential Regulation No. 22 of 2017 concerning the General Plan of National Energy (RUEN) (Presiden Republik Indonesia, 2017). The RUEN has even been broken down into a number of Regional Energy General Plans (RUED) at the provincial level in the form of Regional Regulations (PERDA) (Dewan Energi Nasional RI, 2021).

Despite its Energy Policy, Indonesia is also bound by several international agreements relating to environmental protection, climate change, and sustainable development, the world's agenda affecting energy plans. For example, goal number 7 of the Sustainable Development Goals (SDGs), which is about "Affordable and Clean Energy", has also been explicated into targets and ways of achieving them by the Indonesian government for Indonesia's context (Kementerian PPN/ Bappenas, n.d.)

Not all of Indonesia's energy policies and the various world development agendas are in the same pathways to achieve their goals. This becomes obvious when the analysis is carried out in more detail. However, different thoughts from various competent sources might be considered to improve the current Indonesia's energy planning. However, it should not fundamentally affect matters that have been previously considered in Indonesia's energy planning for the future.

ARTICLE INFO
Received: March 29, 2021
Received in revised form: April 15, 2021
Accepted: April 15, 2021

doi: 10.46456/jisdep.v2i1.118 (C) 2021 The Author
JISDeP - The Journal of Indonesia Sustainable Development Planning Published by Centre for Planners' Development, Education, and Training (Pusbindiklatren),

Ministry of National Development Planning/ National Development Planning Agency (Bappenas), Republic of Indonesia
Address: Jalan Proklamasi 70,

Central Jakarta, Indonesia 10320

Phone: +62 $2131928280 / 31928285$

Fax: +62 2131928281

E-mail:

journal.pusbindiklatren@bappenas.go.id

Supported by Indonesian Development Planners Association (PPPI) 


\section{The UN-ESCAP's Energy Development Pathways for Indonesia}

One of the 17 goals of the SDGs is goal number 7, "Affordable and Clean Energy" which aims "to ensure access to modern energy that is affordable, reliable and sustainable for all." Achieving this goal will certainly depend on each country's energy-economy-environment problems, even for different regions within a country.

This report (United Nations, 2020) contains recommendations from the United Nations Economic and Social Commission for Asia and the Pacific (UN-ESCAP) to Indonesia regarding steps that the country should take to carry out its energy transition while achieving goal number 7 of the SDGs targeted for 2030. Efforts to achieve goal number 7 will be related to achieving other SDGs goals, such as goal number 13 on "Climate Action."

The critical recommendation presents several energy scenarios. These scenarios would enable Indonesia to achieve the SDG 7 target by 2030 and Nationally Determined Contribution (NDC) of the 2015 Paris Agreement for committed action/emission reduction target in response to climate change. The UNESCAP has developed the National Expert SDG Tool for Energy Planning (NEXSTEP) to produce recommendations specific to Indonesia and other recommendations for other countries.

The report argues that Indonesia's plans to reduce its heavy reliance on fossil fuels to an increasing share of renewable energy in its energy mix are good enough. However, more significant efforts must be taken to achieve its intended goals widely. Among the large countries, Indonesia is on track to achieve "near 100\%" electricity access by 2020.

It is a complex and difficult task to link energy needs with the economic growth expectation, reduce emissions and achieve other SDGs' goals. After examining Indonesia's energy-economy data and policy, the report offers several policy recommendations for Indonesia's policymakers to consider, especially in dealing with energy transition to achieve SDG 7 and NDC targets.

First, the recommendations include efforts to achieve universal access for clean cooking that have to increase by three-fold. The report challenges the current plan for expanding city gas networks (that would bring Indonesia to achieve universal access by around 2025) by pointing that the plan will be too costly and time-consuming. On the contrary, this report offers extensive uses of the electric cooking stove, particularly for JAMALI (Java-Madura-Bali) and areas where there is a surplus in electricity supply.

The second recommendation is about accelerating energy conservation efforts. The current target of 1 percent energy intensity reduction is seen as offering a cost-effective way to reduce energy consumption and energy expenditure; however, Indonesia must be strived to achieve this goal well. Third, Indonesia's energy sector should reduce its greenhouse gas emissions by $18 \%$, a higher figure than the country's original target for emission reduction as proposed in its NDC.

Fourth, Indonesia should develop no more new coal-fired power plants as they are no longer costeffective than renewable energies, and the plants should be ceased to avoid emissions lock-in. The last, Indonesia should continue to remove fossil fuel subsidies and encourage the issuance of green financing.

\section{Which pathways? Responses to the recommendations}

Indonesia should stick to and implement its natural gas infrastructure development programs, including the provision of clean cooking facilities for its tens of millions of households. Indonesia is among the most successful in the world at shifting household cooking fuels from kerosene to LPG, accustoming tens of millions of households to gas cooking. However, heavy reliance on LPG has resulted in the country increasingly importing LPG, even though Indonesia has quite sizeable natural gas reserves, which have not yet been developed for fuel in household cooking and other uses. Although investment for natural gas infrastructure development is expensive, carrying out infrastructure development and delivering natural gas is the right pathway Indonesia should take.

Electric stoves can be introduced, but the outreach will be limited and require a long-term plan because the current electricity is generated mainly by coal power. Its use is also currently limited to Java island due to its excess in electricity supply. It is still far away for renewable energy to replace coal in Indonesia. Therefore, sticking to natural gas for cooking is an appropriate medium-term pathway option.

Energy conservation is indeed an effort that must be widely promoted in Indonesia, considering the potential for energy conservation is significant in various sectors of energy use and the process of producing energy. However, support in the form of regulations, institutions, and companies engaged in energy conservation (ESCO: energy services company) is still very limited and needs to be continuously 
developed. Many of the energy conservation efforts would be "low to no cost" and only need a small lifestyle change, for example, by shifting to take public transport than that of passenger cars (Nugroho, 2018b)

The recommendation that Indonesia should increase its target to reduce GHG emissions from its energy sector is good. However, it is also important to consider that the county has other priorities for its energy security, namely expanding energy access for many of its population who have not yet had access to energy services (Nugroho, 2015). Directly developing renewable energy with low carbon emissions may not be the correct answer to the challenge of widespread energy access in the archipelago (Nugroho \& Rustandi, 2020; Pratama \& Purwanto, 2017).

Indonesia will reduce its coal exploitation, but eliminating coal, including in power generation, is a complex proposal that is difficult to implement for a country rich with coal resources (Nugroho, 2018a). While coal is still a low-cost energy source that is relatively abundant in the country, Indonesia will continue to rely on it to grow the economy until affordable and abundant renewable energy sources can be provided.

Reducing fossil fuel subsidies is a challenge that Indonesia continues to face since removing subsidies for kerosene, diesel, and gasoline, not to mention reducing subsidies for LPG and biodiesel. It seems that the challenge of reducing energy subsidies will endure in Indonesia.

Indonesia needs to promote green financing (including green bonds) to finance renewable energy development, but it needs first to solve fundamental domestic problems. So far, Indonesia has not effectively utilized international financing sources for renewable energy development due to its weak institutional capacity.

Which pathways Indonesia should take will depend on the goals set previously. Different goals lead to the consequences of following different pathways (Nugroho, 2019)

Although many recommendations have been made regarding Indonesia's energy policy and related matters, Indonesia needs to remain consistent with its developed pathways (especially those that are legally binding). National energy policies need to be interpreted well at the regional level, given that this vast archipelago country is endowed with various energy sources but faces different energy, economic and environmental problems in each region. 


\section{Commentary on a report:}

\section{Energy Transition Pathways for the 2030 Agenda SDG7 Roadmap for Indonesia (United Nations - ESCAP, 2020)}
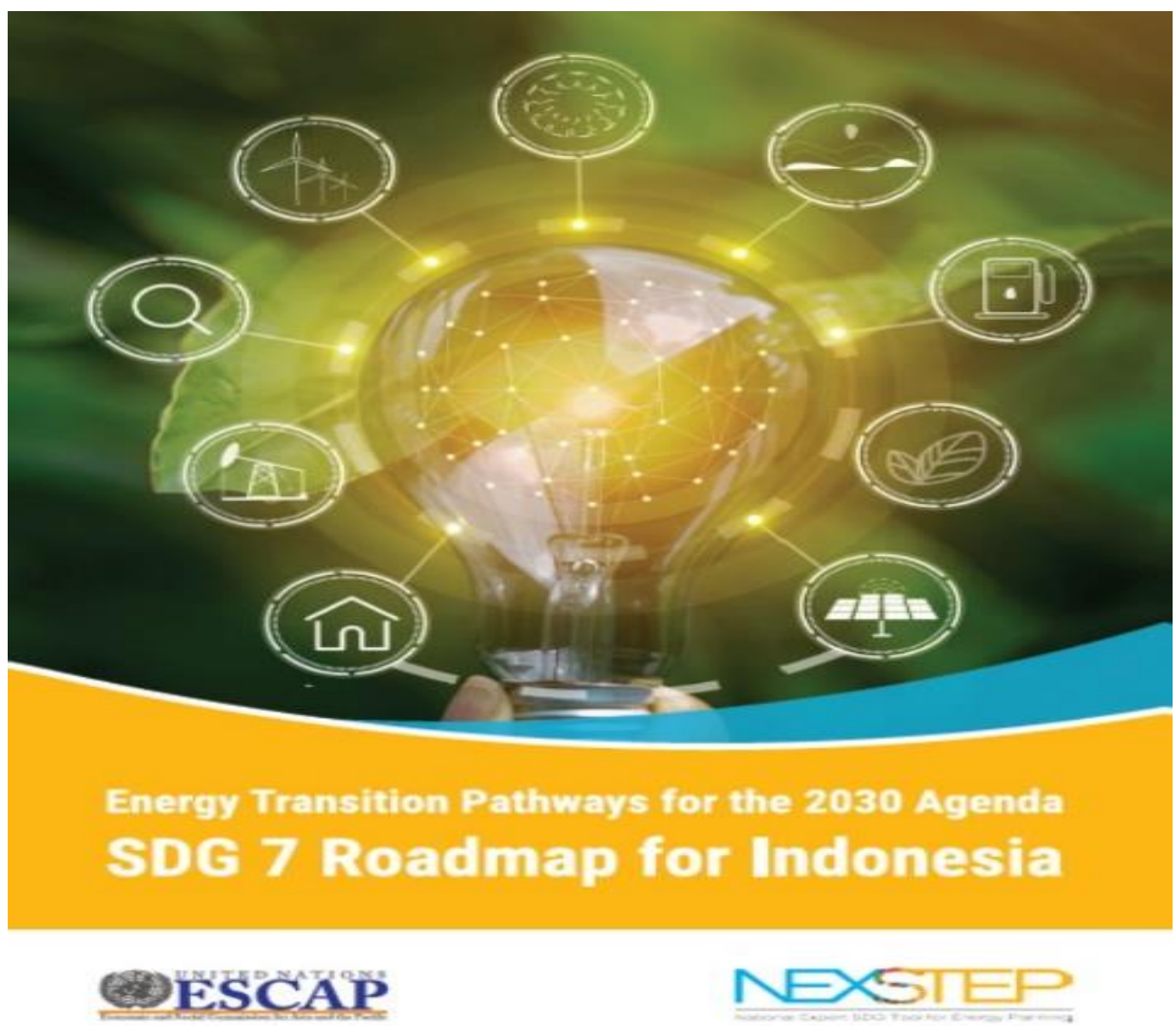

\section{References}

Dewan Energi Nasional RI. (2021). Perkembangan Penyusunan RUED Provinsi 34 Provinsi. Retrieved from Dewan Energi Nasional RI website: https://www.den.go.id/index.php/dinamispage/index/863perkembangan-penyusunan-rued-provinsi-34-provinsi.html

Kementerian PPN/ Bappenas. (n.d.). Sekilas SDGs. Retrieved from Kementerian PPN/ Bappenas website: http://sdgs.bappenas.go.id/sekilas-sdgs/

Nugroho, H. (2015). Redefining Indonesia's Energy Security: Efforts to Adopt Cleaner, More Sustainable Energy Strategies. In National Bureau of Asian Research: Indonesia, a Regional Leader in Transition (pp. 46-59).

Nugroho, H. (2018a). Steep Road: Energy Transition and The Role of Development Planning in Indonesia. Prisma Journal of Social Economy Thoughts, 37(1), 3-19.

Nugroho, H. (2018b). Thought on Indonesian Energy Issues \& Policies. Bogor: IPB Press.

Nugroho, H. (2019). Indonesia's Energy Development: Evaluation of The 2015-2019 Medium-Term Development Plan and Outlook for That of 2020-2024. The Indonesian Journal of Development Planning, 3(3), 266-272.

Nugroho, H., \& Rustandi, D. (2020). An Analysis of The Possibility to Achieve The Specified Indonesian 
Renewable Energy Development Target: Status and Proposal for The 2020-2024 National MediumTerm Development Plan. Hawaii: The IAFOR International Conference on the Sustainability, Energy $\&$ the Environment.

Pratama, Y. W., \& Purwanto, W. W. (2017). Analysis of Indonesia's Renewable Energy Policy: Status, Barriers, and Opportunities. Depok: University of Indonesia Press.

Presiden Republik Indonesia. Peraturan Presiden RI No. 22 Tahun 2017 tentang Rencana Umum Energi Nasional. , Pub. L. No. 22 (2017).

United Nations. (2020). Energy Transition Pathways for the 2030 Agenda SDG7: Roadmap for Indonesia. United Nations Publication. 